\title{
THE BATTLE FOR BAKU (May-September 1918): A PECULIAR EPISODE IN THE HISTORY OF THE CAUCASUS
}

\author{
BÜLENT GÖKAY
}

When the Bolsheviks seized power in Russia in November $1917^{1}$ the First World War had already been approaching its fourth year. Although the Russian armies had controlled the regions of Transcaucasia and part of eastern Anatolia since 1916, on the European borders of Russia the control was in the hands of the Central Powers. The armies of Germany and Austro-Hungary had invaded Russian Poland and had reached the borders of the Ukraine.

It was not a surprise that the urgent task which the new régime in Petrograd set for itself was that of peace. The Russian people were weary of fighting. After four years of war there was a widespread cry for peace among the Russian population. The soldiers particularly wanted to return to their homes. In Lenin's words, "the soldiers are tired out, the soldiers are barefooted, the soldiers are starving, the soldiers do not want to fight". ${ }^{2}$ It is only logical in this context to understand why in the days preceding the November Revolution the Bolsheviks had promised peace. If peace was not forthcoming, if thousands of men were not returning home, it was obvious that Lenin's fate would not be different from that of Alexander Kerensky (the last Prime Minister of the Provisional Government). It was the prowar

\footnotetext{
${ }^{1}$ Until February 1918 (according to the Gregorian calendar which was/is in use in Western Europe) Russia used the Julian calendar. All dates in the Julian calendar are 12 days before in the 19th century and 13 days before in the 20th from the Gregorian calendar. All dates in this text are given in accordance with the Gregorian calendar.

${ }^{2}$ V. I. Lenin, 14-15 October 1917, Collected Works, Moscow, 1964, XXVI, p. 137.
} 
commitments of Kerensky, as described by Taylor, which "opened the door to the Bolsheviks by attempting to revive the war". ${ }^{3}$ The Bolsheviks had to make peace if they were to survive, and this they did.

In the Decree on Peace ${ }^{4}$ on 8 November, Lenin proposed to all those peoples and their governments, who were engaged in war, the immediate opening of negotiations for "a democratic and just peace without annexations and indemnities". He also stated that "the secret treaties must be published" and "the clauses dealing with annexations and indemnities must be annulled". Lenin further proposed an immediate armistice for three months in particular to "the three most advanced nations of the world"- England, France, and Germany. ${ }^{5}$

Britain and its allies considered the Bolsheviks' call for peace with its direct implications on the fronts, as an adverse blow to the Allied war effort. This first act of the new régime presented a radically different attitude from its predecessor, Kerensky's Provisional Government. Russia opted out of the war front as a major power. For Britain, this mean an immediate danger of leaving south Russia and the Caucasus wide open to enemy influence. In the case of the Bolsheviks' making a peace with the Central Powers, it would be highly optimistic to expect decisive results against Germany and its allies in near future. ${ }^{6}$

The Germans had 76 divisions on their Eastern front in March 1917, and the Allies did not want these to be moved to the West. The transfer of as many as two million German soldiers from the Eastern to the Western front raised the distinct possibility of a German victory. ${ }^{7}$ It secmed vital, therefore, to keep the Germans and their allies occupied in the East.

On 21 December the War Cabinet adopted a memorandum, on the proposal of Balfour, Foreign Secretary. The next day Milner, member of the War Cabinet, and Cecil, Minister of Blockade, left for Paris with this

${ }^{3}$ A. J. P. Taylor, The Struggle For Mastery In Europe: 1848. 1918, Oxford, 1954, p. 559.

${ }^{4}$ The Decree on Peace was passed by the Second All-Russian Congress of Soviets of Workers' and Soldiers' Deputies which met in Petrograd on 7 and 8 November, 1917. Lenin, Collected Works, XXVI, pp. 243-263.

${ }^{5}$ Dokumenty Vneshnei Politiki SSSR, Moscow, 1957, I, pp. 11-14. Pravda, 28 November 1917, p. 1. An English translation in Lenin, Collected Works, XXVI, pp. 249-253.

${ }^{6}$ D. Lloyd George, War Memoirs of David Lloyd George, London, 1936, II, pp. 1544-1552.

${ }^{7}$ A. Clayton, The British Empire As a Superpower: 1919-39, London, 1986, p. 46. 
memorandum to submit to the French Premier Clemenceau. According to the memorandum, to continue regular contacts with the Ukraine, the Cossacks, Finland, Siberia, and the Caucasus would be necessary on both the grounds of moral obligation and the strategic importance of these regions. ${ }^{8}$ This memorandum was accepted by Clemenceau the next day and became the Anglo-French Convention. ${ }^{9}$ With this convention two central elements of the Allied policy were put forward: On the one hand to prevent Germany and its allies from obtaining rich material sources (especially the oil of Azerbaijan and the wheat of the Ukraine) and on the other to stop the escalation of the Turkish influence in the region. It was emphasised that a Pan-Turkic and Islamic expansion from Turkey into the heart of the Caucasus might have been even greater danger to the peace of the western world. ${ }^{10}$

The source of this concern about the development of a Pan-Turkic movement "that will extend from Constantinople to China"11 was related to an increasing fear. The Ottoman government encouraged by the Bolsheviks' Decree of Peace, was expecting to recover most of its eastern Anatolian and Transcaucasian lands, which had been occupied by the Russian armies since the Summer of 1916. The German-Sovict negotiations provided the Ottoman government an opportunity to put forward further claims in the Caucasus where a considerable Muslim population had already been stirred up by PanTurkic and Islamic sentiments. ${ }^{12}$ The possibility of an imminent Turkish expansion in the region presented "a new and a very real danger" to the British position in the East. ${ }^{13}$

In this way, the Caucasus emerged as "the most vital [area] from the point of view of British interests" 14 soon after the Bolsheviks Revolution. The British Empire had long considered the region strategically vital to its power in Persia, Afghanistan and, most important of all, in India. When the

${ }^{8}$ In Lloyd George, War Memoirs, II, pp. 1550-51.

${ }^{9}$ The text of this convention is printed in French in Documents on British Foreign Policy 1919-1939, London, 1954, III, ed., E.L. Woodward R. Butler, pp. 369-370, and an English translation of it in Department of State, Foreign Relations of the United States, 1918, Russia, Washington, 1931, I, pp. 330-331.

${ }^{10}$ Ibid., Lloyd George, War Memoirs, II, pp. 1550-51;

${ }^{11}$ Lloyd George, War Memoirs, II, 1551.

${ }^{12}$ Ş. S. Aydemir, Makedonya'dan Orta Asya'ya Enver Paşa, Istanbul, 1972, III, pp. 392-294.

${ }^{13}$ Lord Alfred Milner pointed out the 'danger' of Turkish expansion at the beginning of 1918. (Given by F. Stanwood, War, Revolution and British Imperialism in Central $\Lambda$ sia, London, 1983, p. 63.

${ }^{14}$ Lord Milner at the beginning of 1918 , in Stanwood, War Revolution and British Imperialism, p. 63. 
Bolsheviks proposed an armistice, the anticipation was that the region would fall into chaos. This in turn would make the area vulnerable to the influence of both German and Turkish armies who would not waste time to grab the golden opportunity to put the region under their control.

With the fear of losing the strategic positions and the valuable natural resources of the Caucasus to the Central Powers, the British government encouraged the Christian nations of the region to erect a firm barrier. At the same time, they provided material assistance to the anti-Bolshevik Russian armies. British agents and officers were sent in to advise and support the governments of Transcaucasia and anti-Bolshevik armies. ${ }^{15}$ Even if the Bolsheviks had reached a separate peace agreement with the Central Powers, the Allied-supported bloc was hoped to prevent the fall of the key routes to the German and Turkish powers.

By the end of the year 1917, it appeared that the fear of the British was not ill-founded. All the indications from the region pointed to an immediatc occupation of Transcaucasia by the Ottoman armies in a fresh attempt to realise their long-standing dream of unifying the Turkic-speaking Muslim peoples of the Caucasus, Transcaspia and Central Asia under the Turkish banner.

The decision of the new régime in Petrograd to end the hostilities on the fronts strengthened the expectations of the Turks. This provided a real chance for the Turkish army to exercise its influence in the region without any serious opposition. They were taking advantage of the disintegration of the Russian Eastern front. General Ludendorf, the Deputy Chief of the German Gencral Staff, describes in his memoirs how the Turks captured the opportunity created by the revolution in Russia to fill the resulting political and military vacuum in the Caucasus as "the predestined moment" for the realisation of all their ambitious schemes of expansion. ${ }^{16}$

Enver Pasha, Ottoman War Minister and the most-celebrated champion of the Pan-Turkic expansion, had already sent two division from the Galician and Moldovian fronts to the Turkish-Russian border in the east during the last year of the war. The intention was to create a sound military base in the Caucasus in case of an Allied-occupation of Western Turkey. ${ }^{17}$

\footnotetext{
${ }^{15}$ Telegrams from Page (London) to the Secretary of State, 18, 19 and 21 December 1917, Department of State, Foreign Relations of the United States, 1918, Russia, II, 1931, pp. 591-96.

${ }^{16}$ E. von Ludendorf, My War Memoirs: 1914-1918, London, 1919, II, p. 620 .

17 A. F. Cebesoy, Milli Mücadele Hatıraları, Istanbul, 1953, p. 42.
} 
During the peace negotiations between the Central Powers and Soviet Russia, which started in December 1917, the Turkish expectations regarding the Caucasus significantly increased. Soon after the negotiations started, the Turkish representatives put forward a demand for Ardahan, Kars, and Batum vilayets $^{18}$, which had been given to Russia with the Berlin Treaty (1878). ${ }^{19}$

The treaty of Brest-Litovsk, signed on 3 March 1918, provided the much appreciated and diplomatically tailored legal framework to the Turkish armies to advance in the Caucasus. Despite the demoralising defeat of their armies on the Syrian, Mesopotamian and European fronts, the Turkish delegation at Brest-Litovsk secured significant gains. Three key vilayets, Ardahan, Kars and Batum, would be separated from Russian territory. The importance of this retrocession of the three vilayets lay not so much in the return to Turkey of the great fortress of Kars, but in the fact that Batum was the key port for the rich Baku petroleum. ${ }^{20}$

When the Bolsheviks at the Brest-Litovsk Conference ceded Batum, Kars and Ardahan to Turkey this caused a decp anxicty in the Caucasus. The region itself, as elsewhere in Russia, was on the brink of chaos after Kerensky's downfall in Petrograd. The whole area, situated between the Black and Caspian Scas, is divided by the chain of the Caucasian Mountains into two distincts parts: north Caucasus and Transcaucasia.

In the north Caucasus the representatives of the Terek Cossacks refused to recognise the Bolshevik régime in Petrograd. The Mountain Peoples of the north Caucasus and Daghestan followed the suit, and as a result of a series of meetings, the central authorities of the Terek Cossacks and the Mountain Pcoples set up a 'Provisional Terek-Daghestan Government' in early December. ${ }^{21}$ The Provisional Terek-Daghestan government assumed authority in the entire area of the north Caucasus, the

${ }^{18}$ The Vilayets were large administrative divisions. In 1864 the empire had been divided between 27 of them. The Vilayet was divided into Sanjacks; the Sanjack into Kazas; the Kaza into Nahiyes and villages.

${ }^{19} \mathrm{~S}$. Yerasimos, Türk-Sovyet Ilişkileri, 1stanbul, 1979, pp. 17-19; G. Gratz and R. Schuller, The Economic Policy of Austria-Hungary during the War, New Haven, 1928, p. 114.

${ }^{20} \mathrm{General}$ accounts of the Turkish gains at the Brest treaty include J.W. Wheeler-Bennett, Brest-Litovsk: The Forgotten Peace, London, 1939, p. 272; and A.E. Miller, Ocherki Noveishei Istorii Turtsii, Moscow and Leningrad, 1948, pp. 66-67.

${ }^{21}$ A. N. Kurat, Türkiye ve Rusya, Ankara, 1970, pp. 671-2; R. Kh. Gugov, Sovmestnaia bor'ba narodov Tereka za Sovetskuiu vlast; Nal'chik, 1957, p. 192. 
capital of the new republic being Vladikavkaz, the Russian city at the edge of the mountains on the end the Georgian Military Road. ${ }^{22}$

South of the Caucasus Mountains lay Transcaucasia, extending over an area of 74,000 sq miles. Georgian, Armenian and Azerbaijani peoples have been living in this area. In November when the Bolsheviks seized power in Russia, a meeting of the representatives of Georgia, Azerbaijan and Armenia took place in Tiflis and established an interim government for the region under the title of 'Transcaucasian Commissariat'. 23

The new Transcaucasian government declared its intention to retain power until the Constituent Assembly would convene. The delegates of the Transcaucasian Commissariat began to function independently immediately after the dissolution of the Russian Constituent Assembly by the Bolsheviks on 19 January, 1918. ${ }^{24}$ A representative assembly, the Seim, was formed with the participation of the representatives of Georgia, Armenia and Azerbaijan. In April, 1918, the Seim proclaimed Transcaucasia an independent Democratic Federative Republic, and a cabinet was formed with executive powers. 25

The Seim did not recognise the outcome of the Brest-Litovsk conference; in fact, it had attempted to enter separate negotiations with the Turks in February while the discussions were still going on at BrestLitovsk. ${ }^{26}$ Increasing activities of the Turks in the region accounted for this decision. The Ottoman troops were concentrating in large numbers and Russia, one of the most powerful of the Allies in the region, was already negotiating a humiliating peace with the Central Powers. Under these circumstances, it might have appeared to be the most realistic way to survive to come to terms with the Turks. Two days before the conclusion of the

${ }^{22}$ From the statement issued by the Georgian Information Bureau, London, 26 June 1918, Department of State, Foreign Relations of the United States, 1918, Russia, II, pp. 634-7.

${ }^{23}$ F. Kazemzadeh, The Struggle for Transcaucasia: 1917-1921, New York, 1951, p. 55; R. G. Hovannisian, Armenia of the Road to Independence, 1918, Berkeley/Los Angeles, 1967, p. 107.

${ }^{24}$ Elections to the Constituent Assembly took place in late November 1917. Of the 707 elected members of the assembly the SRs had a comfortable majority of 410 . The Bolsheviks could secure less than a quarter of the seats, i.e. 175. E. H. Carr, The Bolshevik Revolution, London, 1975, I, pp. 120.

25 Dokumenty i materialy po vneshnei politike Zakavkaz'ia i Gruzii, Tiflis, 1919, pp. 27-28.

${ }^{26}$ Yerasimos, Türk-Sovyet Ilişkileri, p. 19. 
Brest-Litovsk treaty, the Seim chose a delegation to negotiate with the Turks in the name of the Transcaucasian Assembly. 27

Transcaucasian and Turkish delegations met at Trabzon, a southeastern Black Sca port, to discuss peace terms at a conference which started on 14 March. ${ }^{28}$ When the supplementary Turkish-Russian agreement to the treaty of Brest-Litovsk, which had already ceded Batum, Kars and Ardahan to Turkey, was put forward by the Turkish delegation as a precondition for the talks, the negotiations entered into a deadlock. ${ }^{29}$

The Transcaucasian government mobilised the army in order to prevent what they perceived as an imminent Turkish invasion of the three vilayets. After stubborn fighting, the Turkish forces penetrated into the eastern part of Transcaucasia where they conveniently joined hands with the Azerbaijani Tatars who were not enthusiastic supporters of the Seim after all. 30

While the Turkish armies were slowly advancing from the south following the deadlock in the Trabzon negotiations, three-hundred miles away in Baku there were major clashes between the local Muslims and the Bolsheviks. Baku was the only town in Transcaucasia with a strong Bolshevik existence.

Following the March Revolution in Petrograd a 'dual power' (dvoevlastie) emerged in Baku as well as in the other big cities of Transcaucasia. On 4 March with the directives from the Provisional Government in Petrograd an 'Executive Committce of Public Organisation' (Ispolnite'nyi Komitet Obshchestvennykh Organizatsii) was established in Baku to act as the local organ of the new central government. Two days later, the Baku Soviet of Workers' Deputies had its first meeting with the participation of fifty-two delegates and elected Stepan Shaumian as chairman in absentia. Shaumian returned two days later from exile and assumed the leadership of the Baku Soviet. After the Bolsheviks' seizure of power in

${ }^{27}$ Iulii Federovich Semenov, "Zakavkazskaia respublika", Vorozhdenie, Paris, Jan. 1949. (A chapter from unpublished memoirs of the only Kadet member of the Transcaucasian Seim), p. 123, given in Department of State, Foreign Relations of the United States, 1918, Russia, II, pp. 619-620.

${ }^{28}$ A. Gadzhiev, Iz Istorii Obrazovaniia i Paderia Iugo-zapadnoi Kavkazskoi (Karskoi) Demokraticheskoi Respubliki, Baku, 1992, pp. 6-7.

29 Kurat, Türkiye ve Rusya, pp. 467-473.

${ }^{30}$ Yerasimos, Türk Sovyet Ilişkileri, pp. 21-22; T. Swictochowski, Müslüman Cemaatten Ulusal Kimliğe Rus Azerbaycanı: 19051920, Istanbul, 1988, p. 167. 
Petrograd the Baku Bolsheviks did not follow suit and preferred to pursue 'peaceful transition' through the political struggle with the local government. 31

Baku, a town with a population of 2500 at the beginning of the nineteenth century, emerged as an industrial and commercial centre with a thriving population rising to 200,000 at the end of the century. The rush to Baku was driven by the discovery of rich oil resources. When the oil wells in Baku started producing the black gold, Tsarist Russia had begun exporting petroleum instead of importing it. Railways soon followed to transport the material wealth to and from. The Batum-Baku railway construction opened the way for a big harbour and, consequently, Baku was by 1918 at the centre of ever important transit route between Russia, Iran and Central Asia via the Caspian sea.

The population of Baku consisted of three major nationalities Azerbaijanis, Russians and Armenians, Each ethnic group had its own political organisation. The Armenians centred around the Dashnaktsutiun, a 'socialist' party with a strong emphasis upon Armenian national unity; the majority of the Azerbaijanis developed some loyalty to the secular nationalist Musavat Party; and the Russians were close to the SRP (Socialist Revolutionaries) and the Mensheviks. However, there was a rising sympathy towards the Bolsheviks since the March Revolution. The real issue in Baku was the danger of an ethnic war between the Armenian and the Muslim communitics,

When the Caucasian front disintegrated completely following the Bolshevik Decree of Peace, there remained virtually no army of which the Baku Soviet could rely on. As a result, an uneasy cooperation emerged between the Bolsheviks and the Armenian Dashnaktsutiun. The Bolsheviks had no choice but to rely on the volunteer units of the Armenians. This new development increased the ethnic and religious hostilities and further alienated the Muslim community in Baku.

Within this unstable atmosphere the Azerbaijani Muslims took up arms as well. The Tatar cavalry regiment of the Touzemnaia (Native) Division, unofficially known as the Dikaia (Wild) Division ${ }^{32}$ transferred $^{2}$

${ }^{31}$ R. G. Suny, The Baku Commune: 1917-1918, Princeton, 1972, pp.72-75; Swietochowski, Müslüman Cemaatten Ulusal Kimliğe, p. 124.

${ }^{32}$ Special cavalry units of Muslims from the Turkestan and the Caucasus were formed and incorporated into the Russian Army in the war. The largest was the Wild Division. G. P. Tschebotarioff, Russia, My Native Land, New York, London, Toronto, 1964, p. 101. 
from Petrograd was the nucleus of these Muslim formations. Starting from the beginning of 1918, sporadic fights broke out in the region between the Muslims and Christian Russians and Armenians. The situation became more tense in Baku when the Armenian military units became the chicf political ally of the Bolsheviks. The emergence of a new wave of armed confrontation was a high possibility, only in want of a spark.

The ignition flared up in late March. On 24 March a shipload of Muslim soldiers of the Wild Division arrived in Baku and resisted orders of the Baku Soviet to disarm. The Armenians first declared their neutrality as Muslim rebellion started against the authority of the local Sovict. But the clash immediately developed into a racial and religious warfare when the Armenian units joined forces against the Muslims. Within a day the Bolsheviks supported by the Armenian units fought a very violent war against the Baku Muslims led by the Musavat. The fighting lasted three days and Musavat was defeated. There were heavy casualties, mostly Azcrbaijani Muslims. According to Shaumian's figures, more than threc-thousand Muslim volunteers were killed. ${ }^{33}$

This episode is described in Soviet historiography as "the victory of revolutionary forces" against the "counter-revolutionary forces" of the Musavatists, the Dashnaks, the SRs and the Mensheviks. The Armenian support in the Baku Bolsheviks' fight against the Muslims was hastily swept aside in order to justify the incident in terms of a "class struggle" between "Transcaucasia's working class, and above all, its vanguard, the Baku proletariat" and the "Azerbaijanian bourgeois-gentry circles". 34

The March event in Baku became the first tragic incident in which the Bolsheviks sought the support of one ethnic power against another to strengthen their position in the region. Following the end of the battle, the Bolsheviks hurriedly started to consolidate their gains. With the Muslim power tragically cut and the Armenians weakened by the battle, there was no one to oppose the full monopoly of power by the Bolsheviks. They absorbed part of the Armenian troops into the Baku Red Army, disbanded the rest, and closed all opposition parties and papers. ${ }^{35}$ The Baku Council of Pcople's Commissars (Sovnarkom) was set up at a meeting of Baku Sovict on 25 April. ${ }^{36}$ It declared itself as the first plenipotentiary Sovict government body

${ }^{33}$ S. G. Shaumian, Izbrannye proizvedeniia, Moscow, 1958, II, p. 209.

${ }^{34}$ L. Mitrokhin, Failure of Three Missions, Moscow, 1987, p. 16; A. I. Mikoyan, Memoirs of Anastas Mikoyan, Madison, Connecticut, 1988, I, p. 107.

35 Ibid., p. 109.

${ }^{36}$ Ibid., p. 110; Suny, The Baku Commune, p. 231. 
in Transcaucasia. ${ }^{37}$ Thus Baku's 'October' arrived five months after the Petrograd's.

For the Azerbaijani Muslims 'March 1918' represents a decisive turning-point. Following their heavy losses they rejected the new authority in Baku and severed all their links with the Bolsheviks, putting their hopes in the advancing Ottoman armies as their potential liberators from their nonMuslim rulers.

While the Baku Bolsheviks were busy in consolidating their gains after the March events, the Ottoman armies continued their advance from the other side of Transcaucasia towards the Caspian shores. By mid-April the Ottoman armies had already occupied Batum and Kars. In the face of rapidly advancing Turkish armies the government of the recently declared Transcaucasian Republic accepted the call of the Turks for a new conference in Batum, then under the Ottoman occupation. ${ }^{38}$

The Batum conference started in early weeks of May. At the conference the Ottoman delegation presented a draft treaty which demanded from the Tiflis guberniia, the Akhalkalak and Akhaltsikh uezds and from the Erevan guberniia, the entire Surmeli uezd along with part of the Alexandropol and Etchmiadzin uczds through which the Kars-Julfa railroad passed. ${ }^{39}$ In addition to these, new substantial privileges on trade and navigation, frontier traffic, full Ottoman transit rights through Transcaucasia, and a sharp reduction of the armed forces of the Transcaucasian government in Tiflis, were demanded. ${ }^{40}$

There seemed nothing to prevent the Turks to put the whole region under their control. The Azerbaijani Muslims were opposed to any resistance to the Turks for they were only too happy to see a Turkish take-over of the whole country. The Armenians, although fearful of such a possibility, were exhausted and disorganised and therefore not able to participate in any kind of opposition to the Turks. Finding themselves in such a desperate situation and

${ }^{37}$ Mitrokhin, Failure of Three Missions, p. 17.

${ }^{38}$ From Vehip Pasha to Akaki Chkhenkeli, the President of the Transcaucasian Republic, 28 Arpil 1918, given in Yerasimos, TürkSovyet Ilişkileri, p. 22.

${ }^{39}$ Guberniia, uezd, volost. Russian administrative territorial unit. The largest of these was the guberniia, divided into uezds, which in turn were subdivided into volosts. This system continued under Sovict power until the introduction of the new system of administrative territorial divisions in 1929-1930.

${ }^{40}$ For Batum Conference see Kurat, Türkiye ve Rusya, pp. 474-476. 
with the fear of complete isolation, the Georgians approached the German General von Lossow with a request for the protection from the Turks. ${ }^{41}$

The Germans were interested in forestalling the advance of the Turkish armies as they were secking control of petroleum and other natural sources in the area for their own benefit. The Georgian demand provided an opportunity for the Germans to set up a strong basis in the region to secure "the raw materials of the Caucasus independently of Turkey". ${ }^{42}$ The representative of the Imperial Chancellor, Colonel Kress von Kressentstein, together with two German officers and with a detachment, arrived in Tiflis and established an intimate relation with the members of the Georgian Diet. ${ }^{43}$

As a result of this guarantee provided by Germany, the Georgian Diet assembled in Tiflis and declared independence of Georgia on 26 May. ${ }^{44}$ With Georgia's declaration of independence, the Transcaucasian Republic, after only a month's existence, came to an end. Two days after the declaration of the independence of Georgia, the independent republics of Armenia and Azerbaijan were declared, with Erevan being the Armenian capital, and Gandzha (Elisavetpol) the Azerbaijani. ${ }^{45}$

On 4 June, 1918, the above three republics signed three separate agreements with the Ottoman Government at Batum, thus ending the Batum Conference. By the treaty of the Brest-Litovsk the Ottoman Empire had acquired nearly 10,000 square miles and six-hundred-thousand inhabitants of Transcaucasia. As a result of the Batum treaty and additional 8,(0)0 square

${ }^{41}$ German army had employed Georgian volunteers in their campaign in Armenia in 1915 and 1916. In so doing the Germans had come in contact with 'influential' Georgians. Ludendorff, My War Memoirs, II, pp. 620621.

42 Ibid., p. 621.

${ }^{43}$ Major Genaral G. M. W. Macdonough, the Director of Military Intelligence, informed the Imperial War Cabinet on 27 June of the arrival of von Kressentstein in the Caucasus; London, PRO; Cab. 23/41. See also Ludendorff, My War Memoirs, II, p. 659.

${ }^{44}$ From the statement issued by the Georgian Information Bureau in London on 26 June 1918, Department of State, Foreign Relations of the United States, 1918, Russia, II, pp. 534-7. Agreement between Georgia and Germany in J. Bunyan, Intervention, Civil War and Communism in Russia, April-December 1918, Documents and Materials, Baltimore, 1936, p. 53.

${ }^{45}$ From the American Consul at Tiflis, Smith, temporarily in Moscow, to the Secretary of State, 16 June 1918, Foreign Relations of the United States, 1918, Russia, II, pp. 632-3. 
miles and six-hundred and fifty-thousand people were added to the Turkish sphere, delivering fresh blood to the ailing Empirc. ${ }^{46}$

The article IV of the Agreement with Azcrbaijan, which accepted that "the Ottoman Government will provide military support to the Azcrbaijani Government if this is seen necessary by the latter for domestic stability and national security", signified the special relationship between the Turks and the Azerbaijanis. ${ }^{47}$ Following this agreement a Turkish army together with Azerbaijani and other muslim volunteers from the region, began to move towards the Caspian against the Russian Bolsheviks and the Armenians who was in control in Baku since the tragic 'March days'. ${ }^{48}$ The Turkish army, called the 'Army of Islam', was under the command of Enver's younger brother, Nuri Pasha, who was known for his extreme pan-Turanian ideas. The first task of Nuri's army was to secure a route from Kars through Julfa to Baku. In this way it would be possible to control the regions of north Persia as well. ${ }^{49}$

In north Persia the British forces were actively involved in operations since the beginning of the year with the goal of reaching the Caspian front from the south to establish contacts with the pro-Allied elements in Transcaucasia. These operations were directed by Major-General Lionel C. Dunsterville, the hero of Kipling's novel Stalky and Co. 50 Dunsterville had been appointed chicf of the British mission to the Caucasus and also British representative at Tiflis in January $1918 .{ }^{51}$ His sphere of work was to extent over all Russian and Turkish territories south of the main chain of the Caucasus. The primary military objective of Dunsterville's mission was defined as "the maintenance of an effective force on the Caucasus front so as to protect the occupied portions of Turkish Armenia and to prevent the

${ }^{46}$ A. B. Kadishev, Interventsia i grazhdanskaia voina v Zakavkaz'e, Moscow, 1960, p. 64; Hovannisian, Armenia on the Road of Independence, p. 199.

${ }^{47}$ Yerasimos, Türk-Sovyet Ilişkileri, p. 25; Kurat, Türkiye ve Rusya, p. 664.

${ }^{48}$ Yerasimos, Türk-Sovyet İlişkileri, pp. 27-28.

${ }^{49}$ Ibid., pp. 29-30; also see Hovannissian, Armenia on the Road of Independence, p. 174.

${ }^{50}$ Kipling and Dunsterville had shared a study at the public school Westward Ho in 1880. C. E. Carrington, The Life of Rudyard Kipling, New York, 1955, p. 22).

${ }^{51}$ Ronald MacDonell, the British vice-counsul in Baku, writes in his memoirs that there were a number of British Intelligence Officers in the Caucasus, whose duties "were to prepare, devise or create a situation which would enable General Dunsterville and his force to take charge." R. MacDonell, And Nothing Long, London, 1938, p. 205. 
realisation of Pan-Turanian designs".52 To achieve this objective Dunsterville was to cross the 650 miles between Baghdad and Enzeli and from there to embark his men for Baku and Tiflis. 53

The preparations for Dunsterville's advance in the Caucasus were undertaken by a small number of British military intelligence officers who were attached to a committee in Tiflis called the 'Caucasus Military Agency' under the control of Colonel G. D. Pike. This mission had originally been established to assits the Tsarist Russian armies in the Eastern front. Major G. M. Goldsmith, who was to assist the operations of Dunsterville as 'I', had arrived in Baku on 13 February 1918 with two Ford cars and three men, and soon after procecded to Tiflis to work with the Caucasus Military Agency. Goldsmith had set up relations with the local groups in the region, including the Bolsheviks, and established an efficient communication link with the British forces in north Persia. ${ }^{54}$

Starting from early Junc, Turkish troops were coming closer to the line Dunsterville was trying to hold. ${ }^{55}$ With the extremely favourable terms of the Batum conference the Turkish army had gained an ever increasing foothold for further operations in the region.

In this recent situation the Bolsheviks in Baku and the British in north Persia found themselves under a common threat stemming from the advancing Turkish troops. If the Turks captured Baku and the surrounding oil fields, it seemed obvious that the expectations of the British and ironically those of the Bolsheviks would come to a disappointing end. Once the Turks were established in Baku it would be very difficult to prevent a Turkish advance further eastward into Persia and Transcaspia. One had only to cross the Caspian at its narrowest point to reach Krasnovodsk and to Turkoman steppe, from which could be reached the vast expanse of Turkestan.

52 F. J. Moberly, History of the Great War Based on Official Documents, the Campaign in Mesopotamia, 1914-1918, London, 1923, IV, pp. 104-105.

${ }^{53}$ Dunsterville, The Adventures of Dunsterforce, pp. 11-67.

${ }^{54}$ Major Goldsmith describes his activities with the Caucasus Military Agency in his 86-page report to the Director of Military Intelligence. Goldsmith spent eight months in the region until 6 October 1918 when he and the other members of the Caucasus Military Agency were arrested by the Bolsheviks in Vladikavkaz. From Major G.M. Goldsmith, Acting British Military Agent, Army of Caucasus Front to the Director of Military Intelligence, W.O., 1 July 1919; London, PRO; WO 95/ 4960.

55 From Sir C. Greene (Tokyo) to Balfour, 12 June 1918; London, PRO; FO $371 / 3292$. 
It was, therefore, not surprising for the British and the Bolsheviks to share a common goal in May 1918: to keep the Turks away from Baku and surrounding oil fields. As the Turkish forces were marching against Baku, neither of two parties could afford to be selective about their allies. The small number of British troops could only act as a nucleus for some form of reorganisation of the local forces against the Turkish advance and unless they achieved a kind of understanding with the Baku Bolsheviks, this too seemed quite difficult to be realised. ${ }^{56}$ Indeed, it was one of the first successes of Goldsmith's mission in the region to get a permission from Shaumian in late February to let Dunsterville, together with 40 officers and 50 other ranks with 4 motor cars, to pass through Baku and proceed to Tiflis. ${ }^{57}$

Dunsterville does not mention about the activities of the Caucasus Military Agency in his memoirs. ${ }^{58}$ Neither he makes any reference to Shaumian's permission. But on 22 May he asked General Marshall, General Officer Commanding-in-Chief of the Mesopotamian Expeditionary Force in Baghdad, for permission to collect all available troops and armoured cars to help the defence of Baku against the Turkish forces. On 24 May General Marshall repeated this demand in a telegram to the War Office stating that Dunsterville, with all available force, would be ready to leave for Baku within a weck. 59

Despite the general recognition that there was very little Britain could do by itself, once asked by their military representative in the region the British authorities in London found it very difficult to give consent to any such cooperation with the Bolsheviks. On 27 May the War Office sent a telegram to the Mesopotamian H.Q. saying that "in view of the completely changed situation in the Caucasus, Gencral Dunsterville was not to go there". 60 To this Dunsterville replied that "he did not wish Baku to give up hope and allow the oil to fall into enemy hands". He repeated his earlier demand to give every assistance possible to the defence of Baku. This was repeated in a telegram to the CIGS sent by General Marshall on 4 June. ${ }^{61}$

56 Moberly, History of the Great War Based on Official Documents, the Campaign in Mesopotamia, 1914-1918, IV, p. 179; E. Dane, British Campaigns in the Nearer East. 19141918, London, II, p. 215.

${ }^{57}$ Goldsmith's report to the Director of Military Intelligence, 1 July 1919; London, PRO; WO 95/4960.

58 Moberly makes a few general references to the activities of the Caucasus Military Agency. History of the Great War, pp. 103, 104-105.

${ }^{59}$ Ibid., pp. 172-173.

${ }^{60}$ Ibid.

${ }^{61}$ Ibid., p. 179. 
The CIGS replied General Marshall's telegram on 6 June saying that "without further reference to London and definitive instructions from there" no step was to be taken. ${ }^{62}$ The issue was discussed in the War Cabinet and the Eastern Committee. ${ }^{63}$ The conclusion of these discussions was the same with the CIGS's instructions to General Marshall: it was not desirable to send the British troops to Baku. ${ }^{64}$

The reasons for this refusal were probably threefold. In the first place, the Eastern Committee feared that once the troops had gone there they would incvitably be overwhelmed by the vastly more numerous Turkish forces. Second, Lord Curzon, the Committec's chairman, insisted on his colleagues that the foundation of their policy had been to build a barrier against the Turks in northern Persia and if Dunsterville transferred any of his forces to Baku it was feared that the Persian barricr would be weakened. ${ }^{65}$ Finally, Lloyd George provided the ultimate and perhaps the most significant reason to why the British could and would not cooperate with the Bolsheviks. In a War Cabinet mecting in June he stated that "it would be better for us the Turks to hold Baku", rather than the "Russian Bear", since he believed that "it was not probable they [the Turks] would ever be dangerous to our [British] interests in the East, whilst, on the other hand, Russia, if in the future she became regenerated, might be so". 66

Interesting enough, Moscow's reaction to the issue of inviting the British to help the defence of Baku against the Turks was exactly the same as London's. The Bolshevik government refused to allow Dunsterville to pass unimpended to Baku. Instead of handing Baku to the 'British imperialists', it was preferred to let the Turks to capture it. Similar to the opinion in London, Moscow believed that the Turkish rule in the city would not be permanent. The Baku Bolsheviks were urged to oppose categorically the idea of inviting British troops for the defence of the city. ${ }^{67}$

62 Ibid.

${ }^{63}$ Eastern Committee was established in March 1918 by the War Cabinet to administer the British policy over a vast area between the eastern Mediterranean and the frontiers of India. R. Ullman, Intervention and the War, Princeton, 1961, p. 307, n. 16.

${ }^{64}$ Details of the discussions in London in Ullman, Intervention and the War, p. 307.

${ }^{65}$ From Eastern Committee Minutes, 38 May and 31 May 1918, given in Ullman, Intervention and War, p. 307.

${ }^{66}$ Lloyd George in the War Cabinet, 24 June 1918; London, PRO; War Cab. 435, Min. 8, CAB 23/6.

${ }^{67}$ Mikoyan, Memoirs of Anastas Mikoyan, I, pp. 135-7. 
The official opposition both from London and Moscow, however, did not stop their local representatives to consider such a cooperation and establish some contacts. Goldsmith describes in his report that the Baku Bolsheviks "actually assisted" the Caucasus Military Agency "in preventing food transports" by the Germans. In Vladikavkaz, too, the Bolsheviks cooperated with the Caucasus Military Agency to check the German and Turkish advance in the north Caucasus. Goldsmith provides Russian and English copies of a detailed action plan prepared by Colonel Pike alongside with the Vladikavkaz Bolsheviks. According to this the Georgian Military Road, together with the railway station in Vladikavkaz, were controlled by a combined team of the British and Bolsheviks "against the German and Turkish agents..." 68

In addition to Goldsmith's account Ronald MacDonell, the British vice-consul in Baku, provided some extra confirmation of this in his personal account of the events. According to MacDonell the leader of the Baku Bolsheviks, Shaumian, had a number of mectings with him in May and, although reluctantly, considered to invite the British forces to Baku to help the city's defences. ${ }^{69}$

There were other examples to the cooperation between the local Bolsheviks and the British. As a result of the negotiations in Enzeli, Dunsterville arranged with the local Bolshevik committec to sell Ford cars to the Baku Soviet in exchange for fucl. Fifty-thousand pounds of gasoline was bought in return to ten Fords by the end of July. ${ }^{70}$ The barter of ten Ford cars with petroleum was cited by Colonel Rawlinson as well. Rawlinson was from 7 July onwards under the orders of Dunsterville. ${ }^{71}$

During all this time the Turkish army was rapidly advancing towards Baku, and the city was surrounded by mid-June. Regardless of the Bolsheviks' refusal, the Armenian Dashnakists, who actually constituted the majority of

${ }^{68}$ Goldsmith's report to the Director of Military Intelligence, 1 July 1919; London, PRO; WO 95/ 4960.

${ }^{69} \mathrm{MacDonell}, \mathrm{A}$ nd Nothing Long, pp. 210-2, 251.

${ }^{70}$ Dunsterville, The Adventures of Dunsterforce, p. 170.

${ }^{71}$ A. Rawlinson, Adventures in the Near East, London, 1934, p. 65. Goldsmith provides some extra information about Rawlinson's movements, according to which Rawlinson was in the Caucasus since early 1918 on a secret mission, disguised as Mr Robinson, an American engineer. There is no reference to this particular mission in Rawlinson's own account. Goldsmith's report to the Director of Military Intelligence, 1 July 1919; London, PRO; WO 95/ 4960. 
the Baku Red Army, sent a delegation to the British General Dunsterville and asked for help in defence of Baku against the Turks. ${ }^{72}$

First, Colonel Lazar Bicherakhov, the Russian leader with whose 1800 Cossack-force Dunsterville had been cooperating, went and offered his troops to the Baku Soviet. Both Dunsterville and Rawlinson indicate that this ofter was clearly initiated and implemented by Dunsterville as a substitute after London clearly refused the proposal to move the British troops to Baku to organise the defence of the city together with the Bolsheviks. ${ }^{73}$ In his letter to the Baku Council of People's Commissars, Bicherakhov wrotc: 'I am not a Bolshevik or Menshevik. I love my country, know how to fight a bit and am coming to help the Baku Sovict defend the city of Baku from the Turkish invasion. ${ }^{74}$ Despite his record of antiBolshevik activities, the Baku bolsheviks did not oppose this offer and Bicherakhov was welcomed in Baku. 75

Bicherakhov and his regiment, accompanied by a few British officers, with two armoured trains, artillery, and armoured cars, reached Alyat, a port some 35 miles south of Baku, carly in July and immediately started to combat with the Turks. ${ }^{76} \mathrm{He}$ was appointed commanding officer of one of the chicf units of the Baku Red Army. ${ }^{77}$ On 9 July the Baku Izvestiia was carrying a confident message from Bicherakhov saying that the chances of the Turkish army were little in the face of the young Red Army. ${ }^{78}$ However, this optimism was short-lived. Bicherakhov's troops were outnumbered, and

${ }^{72}$ See Mitrokhin, Failure of Three Missions, pp. 39-40; Dunsterville, The Adventures of Dunsterforce, p. 208; G. A. Brinkley, The Volunteer Army and Allied Intervention in South Russia, 1917-1921, Paris, 1966, p. 63.

${ }^{73}$ Rawlinson, Adventures in the Near East, pp. 64-67; Dunsterville, Adventures of Dunsterforce, pp.

${ }^{74}$ Given in Mitrokhin, Failure of Three Missions, p. 45.

${ }^{75}$ Moberly, History of the Great War, IV, p. 183; Kazemzadeh, The Struggle for Transcaucasia, pp. 133-4.

${ }^{76}$ Mikoyan states in his memoirs that "to be on the safe side, it was decided not to have him [Bicherakhov] enter Baku, but to have him halt at the Aliat [Alyat] Station...", Memoirs of Anastas Mikoyan, I, pp. 120121.

${ }^{77}$ Dunsterville, The Adventures of Dunsterforce, pp. 196-7. MajorGeneral Macdonough, Director of British Military Intelligence, however, seems to have been misinformed about Bicherakhov's movements. Both on 23 July and 20 August he informed the Imperial War Cabinet that "Bicherakhov had never gone to Baku". Imperial War Cabinet Minutes, London, PRO; Cab. 23/41 and Cab. 23/42.

${ }^{78}$ Izvestiia (Baku), 9 July 1918, in Suny, The Baku Commune: 1917-1918, p. 291. 
they could not hold the front against the Turkish infantry and artillery for long. After holding back the Turks for about a weck, he withdrew his troops from the front and retreated to Derbent and Petrovsk in Daghestan. ${ }^{79}$

The Turkish forces on the other hand were pursuing their march with even greater determination. By the end of June, new divisions from the Western front had arrived in the Caucasus, where threc Ottoman armics were waiting for the instructions of Enver Pasha. The Third Army (composed of the 3rd, 5th, 36th, and 37th Caucasian divisions) was charged with maintaining order in all territories acquired by the treaties of Brest-Litovsk and Batum. The newly organised Ninth Army (made up of the 9th, 10th, and 11th Caucasian divisons) was bestowed upon Yakub Sevki Pasha, whose temporary headquarters were in Alexandropol. Together, the Ninth Army and the Sixth Army (the latter located in North Persia) constituted the Army Group of the East under the supreme command of Enver's uncle, Halil Pasha. The ambitious task of liberating Baku and expelling the British from Persia and Baghdad rested upon these troops.

Already Mürscl Pasha's 5th Caucasian Division was in transit to Gandzha, where it was to form the nucleus of "Army of Islam" and bolster Ali Agha Shikhlinskii's Azerbaijani forces. The Germans, having reached a preliminary understanding with the Ottomans, withdrew their units to a line of villages north of the Kamenka River - thus alloving Mürsel's men to pass from Alexandropol and Karakilise into the Alisavetpol guberniia. Kress von Kressentstein now counselled the Georgian government to let the Turks trespass in the southernmost parts of the Tiflis gubernii. ${ }^{80}$

On 16 July 1918, the Dashnaks in the Baku Soviet, this time together with the SRs, put another motion to extent an official invitation to the British. The proposal was narrowly defeated but it had received so much support that Shaumian decided to ask for instructions from the Bolshevik central authorities. Moscow repeated its previous decision, and ordered Shaumian to combat the Baku Sovict's "unpardonable disposition" to appeal for British aid. Were Baku to fall, it would be better that the Ottoman Turks - not the experienced English colonialists - become the temporary heir to the invaluable city and its resources. ${ }^{81}$

\footnotetext{
${ }^{79}$ From Senior Naval Officer (Baghdad) to Admiralty, 10 November 1918, London PRO; FO 371/ 3347. Mikoyan, Memoirs of Anastas Mikoyan, I, p. 121.

${ }^{80}$ Hovannisian, Armenia on the Road of Independence, pp. 204-5.

${ }^{81}$ Stalin, 21 July 1918, Dokumenty Vneshnei Politiki SSSR, I, pp. 401-2. All this correspondence is summarised in the letter from Shaumian to Lenin, 31 July 1918; Moscow, TsPA [Central Party Archive]; Fond: 160, Op.: 3, D.: 6 .
} 
During the last couple of weeks of July 1918 the possibility of a Turkish invasion of Baku drew ever so closer. The arrival of new divisions from the Western front reinforced the capability of the Turkish forces. The Bolshevik leaders of Russia could offer little help. According to Soviet historians, the Bolshevik government in Moscow, with the directives of 'the Great Leader', was considering to send a significant number of Red Army troops to defend Baku. ${ }^{82}$ But in the end only a cavalry force of about 170 men came from Astrakhan and a detachment of 780 infantry from Central Asia. ${ }^{83}$

On 25 July the Turkish armies reached Alyat, and on the same day at the meeting of the Baku Sovict (despite the opposition of Shaumian), a final motion to seek British military aid was voted and accepted by a small margin (259 to 236). ${ }^{84}$ Shaumian declared that he regarded the decision as "a disgraceful betrayal" 85 and, as a representative of the central Soviet power, he declined to burden the responsibility, and six days later the Bolsheviks withdrew from the Baku Sovict. ${ }^{86}$ On the following day this was replaced by the Centro-Caspian Directorate - a coalition dominated by SRs and composed of the Russians and the Armenians. ${ }^{87}$ As its first act, the Centro-Caspian Directorate officially invited Dunsterville to protect Baku. ${ }^{88}$

${ }^{82}$ P. Azizbekova, A. Mnatsakanyan and M. Traskunov, Sovetskaia Rossia i Borba za Ustanovlenie i Uprochenie Vlasti Sovetov v Zakavkaze, Baku, 1969, p. 97.

${ }^{83}$ Given in Suny, Baku Commune, p. 316.

${ }^{84}$ Telegramme from Shaumian (Baku) to Lenin, 27 July 1918, Dokumenty Vneshnei Politiki SSSR, I, pp. 411-412.

${ }^{85}$ Given by S. I. Aralov, Vospominaniia Sovetskogo Diplomato, Moscow, 1960 , p. 23

${ }^{86}$ Shaumian and 25 other Baku commissars were arrested soon after by an anti-Bolshevik committee based in Ashkabad, and later were taken out into the desert and murdered on 20 September 1918. A full list of the Commissars in A. I. Mikoyan, Dorogoi Borby, Moscow, 1971, I, pp. 226-242. When the news of the massacre reached Moscow in early 1919 the Bolshevik government accused British officers of being responsible for the death of the commissars. Azizbekova, Mnatsakanyan, Traskunov, Sovetokaia Rossia i Borba za Ustanovlenie i Uprochenie Vlasti Sovetov v Zakavkaze, p. 103; Mitrokhin, Failure of Three Missions, p. 49. The British government, however, denied any role in the incident. Great Britain, Parliamentary Papers, Command Paper 1846, Russia No. 1, 1923.

${ }^{87}$ The Centro-Caspian Directorate is described as a "tool of the British imperialism" in Soviet accounts. Aziðbekova, Mnatsakanyan, Traskunov, Sovetskaia Rossia i Borba za Ustanovlenie i Uprochenie 
On the basis of this publicly announced appeal from Baku, Dursterville apparently persuaded London that with the the support of a small British force Baku could successfully resist the Turkish armies. He was given permission to send a total of two British battalions, with supporting artillery and armoured cars. ${ }^{89}$ On 4 August 1918, the first British battalion arrived in Baku. As its first directive, London instructed Dunserville not to hesitate "to dispose of any remaining Bolshevik influence he might find at Baku. 90

During the next couple of wecks more British soldiers landed in Baku. Among those were 70 British troops who arrived with an empty oil-tank steamer on 17 August. Colonel Rawlinson was in charge of this detachment. As soon as he arrived in the British headquarters he was given the title of 'Controller General of the Ordanence' by the Transcaucasian Directorate. Rawlinson immediately started a widespread campaign to collect all available weaponry, ammunition and explosives for the use of the city defences. ${ }^{91}$

It is difficult to give the exact number of the British troops who arrived in Baku in August. Despite the variation in the quoted number of men in various accounts, ${ }^{92}$ it appears that British forces on the ground had been around one-thousand men even by the most exaggerated account. This small force was totally inadequate even for the purpose of compelling the Turks to raise the siege of Baku. ${ }^{93}$ Dunsterville attempted to strengthen the defence of the city by commanding the units of the Dashnaks, SRs and Mensheviks. He soon came to the conclusion that it was not realistic to protect Baku unless

Vlasti Sovetov v Zakavkaze, p. 99; Mitrokhin, Failure of Three Missions, p. 46.

${ }^{88}$ Dunsterville, The Adventures of Dunsterforce, p. 284; Moberly, History of the Great War, IV, pp. 202-3.

${ }^{89}$ Moberly, History of the Great War, IV, pp. 198-199.

90 Ibid., p. 213.

${ }^{91}$ Rawlinson, Adventures in the Near East, pp. 67-9.

92 W. E. D. Allen and P. Muratoff, Caucasian Battlefields: A History of the Wars on the Turco-Caucasian Border: 1828-1921, Cambridge, 1953, p. 492; Dunsterville, The Adventures of Dunsterforce, pp. 230, 284; Kazemzadeh, Struggle for Transcaucasia, p. 139; Moberly, History of the Great War, IV, pp. 105, 216, 246; Mitrokhin, Failure of Three Missions, p. 46; Hovannisian, Armenia on the Road to Independence 1918, p. 222.

${ }^{93}$ Moberly writes that the Turks opposite Baku numbered 5,300 regulars with 26 guns and 8,000 Tatar irregulars under Turkish officers. Moberly, History of the Great War, IV, p. 230. 
extensive military support was provided. Yet none seemed forthcoming from anywhere. ${ }^{94}$

In late August a glimpse of hope emerged more than a thousand miles away to save Baku from the invasion of the Turkish armies. On 27 August, 1918, the German-Soviet talks ended with an additional treaty to the BrestLitovsk. In this treaty the articles related to the Caucasus proclaimed that Soviet Russia would not oppose German recognition of Georgia, and that Russia would deliver to Germany either one-fourth of the petroleum tapped in Baku or a certain monthly minimum to be determined later. In return, Germany would refuse to assist the military operations of a third power (Turkey) in areas beyond the borders of Georgia and, most importantly of all, Germany would strive to prohibit a third power from entering the Baku region..$^{95}$

On paper this supplementary treaty was a serious setback to the advancing Ottoman armies. However, the German troops in the Caucasus were not enough to stop the Turks militarily. Furthermore, the existing German troops and officers were just called back due to "the great efforts made against us [the Germans] on the French front". 96

The Turks were only 35 miles away from the city of Baku. In order to complete a de facto situation the 5th 15th, and 36th divisions of the Caucasian Turkish army were immediately ordered to strike rapidly. In the face of this strong Turkish attack, the German military leaders did not attempt to fulfil those relevant articles of the Brest-Litovsk treaty. They did not deny the Turkish troops' entrance to Baku and even they recommended that a small number of German units should participate in the campaign in order to safeguard some share for themselves. ${ }^{97}$

By the end of August 1918, Dunsterville had definitely decided that "the further defence of Baku is a waste of time and life." $98 \mathrm{He}$ addressed the Baku authorities on 1 September and repeated the same point: "No power on

${ }^{94}$ Dunsterville, The Adventures of Dunsterforce, p. 309.

${ }^{95}$ Russian-German Supplementary Treaty to the Peace Aggreement between Russia, and Germany, Austro-Hungary, Bulgaria and Turkey, 27 August 1918, Dokumenty Vneshnei Politiki SSSR, I, pp. 443-445; an English account of this treaty in Whecler-Bennet, Brest-Litovsk, p. 433;

${ }^{96} \mathrm{~A}$ radio telegram sent by Ludendorff on 28 June was deciphered by the Caucasus Military Agency, in Goldsmith's report; London, PRO; WO $95 / 4960$

97Ibid.; Yerasimos, Türk-Sovyet İlişkileri, pp. 30-31.

${ }^{98}$ Dursterville, The Adventures of Dunsterforce, p. 275. 
earth can save Baku from the Turks. To continue the defence means only to defer the evil moment and cause further needless loss of life."99

London was informed about the situation in Baku on 28 August. On 31 August the War Office telegraphed in reply expressing entire concurrence for a full withdrawal. It was also suggested that Dunsterville should be instructed to destroy the oil-plant at Baku before withdrawal. 100

When on 12 September 'definite and reliable' information arrived (which according to Dunsterville by two Arab deserters from the Ottoman army and according to Rawlinson by an Armenian) about the Turkish plans for the final attack, Dunsterville made the preparations for evacuation. ${ }^{101}$ And on the night of 14 September, with Baku under heavy attack, Dunsterville loaded his men on ships and left the city to its fate. Rawlinson, on the other hand, managed to load most of the ammunition on to a little ship and left the city with large quantities of explosives. Despite the request of the War Office regarding the Baku oil-plant no damage had been done before evacuation, beyond putting the wircless station at Baku out of action. 102

The same night the Turks broke through Baku's final defence parameter. The next day it was declared that the combined TurkishAzerbaijani army captured Baku on behalf of the Azcrbaijani government. ${ }^{103}$

${ }^{99}$ Ibid., p. 279.

${ }^{100}$ Moberly, History of the Great War, IV, p. 230.

${ }^{101}$ Dunsterville, The Adventures of the Dunsterforce, pp. 291-2 and Rawlinson, Adventures in the Near East, p. 83.

102 MacDonell, And Nothing Long, p. 265. The Caucasus Military Agency, on the other hand, had been transferred to Vladikavkaz. when the Turkish armies approached the Tiflis area. There Colonel Pike was accidentally shot on 15 August while watching the street battles between the Bolsheviks and the Terek Cossacks. Goldsmith, who after the death of Pike became the Acting Commanding Officer of the Caucasus Military Agency, and the other members of the mission were arrested in Vladikavkaz by the Bolsheviks in October for being connected to Lockhart conspiracy. Lockhart was then under arrest in Moscow for engineering a counter-revolutionary plot and was eventually sentenced to death. 'Secret and Confidential Memorandum on the Alleged "Allied Conspiracy" in Russia', 5 November 1918; London, PRO; FO 371/ 3348. Members of the Caucasus Military Agency were sent to Moscow in January 1919 and stayed in Butirski prison until July 1919. Goldsmith's Report to the Director of Military Intelligence, 1 July 1919; London, PRO; WO 95/ 4960.

103 Branch Memoranda: South Russia, Caucasus 1918 August-1919 March, by Admiraly Naval Staff Operations Division; London, PRO; WO 106/ 1206. 
A new government was established at Baku, under the leadership of KhanKhoiski who just arrived from Gandzha. ${ }^{104}$

Dunsterville, Rawlinson and MacDonell blamed the local forces especially the Armenians- for the fall of Baku. The Armenians according to their accounts were "undisciplined", "disorganised", "lacked fighting spirit", and "were unable to understand anything about warfare". 105 Some Armenian participants of the events, however, challenged this view by claiming that Dunsterville had initially promised them to bring a much larger force to Baku. Sergei Melik-Lolchian, a member of the Centro-Caspian Directorate, states that Dunsterville had promised that a British army of 5.000 was ready at Enzeli to cmbark for Baku, yet the total number of the British troops and technical personnel in Baku was hardly more than a thousand. ${ }^{106}$

One of the British officers of the adventure, Captain Reginald TeagueJones ${ }^{107}$ of Military Intelligence, indicates in his diary that "in practice the venture was doomed to failure because of two main factors (among many others): the force was too small for the task assigned to it, and it arrived much too latc." 108

The occupation of Baku by the Turkish troops marked the end of this brief but eventfull phase in the Caucasus. The fall of Baku was a significant loss both for the British and the Bolsheviks. The Turkish control of this strategic post meant a certain setback for the British position in the region by opening the wealthy oil resources of Baku to the exploitation of the Central Powers within the threatening proximity of the Asian Empire of the British.

104 Azizbekova, Mnatsakanian and Traskunov, Sovetskaia Rossia i Borba za Ustanovlenie i Uprochenie Vlasti Sovetov v Zakavkaze, pp. 101-102.

105 Dunsterville, The Adventures of the Dunsterforce, p. 261; Rawlinson, Adventures in the Near East, pp, 73, 80; MacDonell, And Nothing Long, p. 279.

${ }^{106}$ Given by A.H. Arslanian, "Dunsterville's Adventures: A Reappraisal", Internatonal Journal of Middle Eastern Studies, XXII/2 (September 1980), p. 209.

107 Teague-Jones was accused by the Bolshevik government of being personally responsible for the deaths of the twenty-six Baku commissars. Preferring not to risk Moscow's vengeance, Teague-Jones changed his name and disappeared from view. He spent the rest of his life until his death in 1988 behind the false identity of Ronald Sinclair. Peter Hopkirk's introduction to Teague-Jones, The Spy Who Disappeared, London, 1990, pp. 11-12.

${ }^{108}$ Diary of A Secret Mission to Russian Central Asia in 1918 by Reginald Teague-Jones, entrance 24.8.1918, in Teague-Jones, The Spy Who Disappeared, p. 101. 
For the Bolsheviks this episode signified the end of their only power base in the whole region of the Caucasus, at the same time increasing the potential dangers stemmed from an anti-Bolshevik Muslim campaign towards Transcaspia and the Central Asia.

In the face of the advancing Turkish armies both Moscow and London officially refused to cooperate. This was despite to the fact that, (as Ullman states in the first volume of his Anglo-Soviet Relations) "there was an assumption" on the British side that there did "exist a community of interest between the Allies and the Soviet régime". 109

As illustrated by the events of Transcausia from May to September, 1918 , there indecd existed such an assumption not on the British side only but also among the Bolsheviks. In the face of the immediate danger of a Turkish take-over of Baku and surrounding oilfields, both the representatives of the British and those of the central Soviet government in the region found themselves to be on the same side. Both wanted to keep the Turks out of Baku. Despite the existence of the major differences both sides came close to such an assumption that they had a common interest at that vital point.

The policy-makers of each side, however, did not share the same view. They were too busy to read the long-term implications of the other government's policy. Therefore, the assumption that both Britain and Soviet Russia had a common interest did not exist at the governmental level. The British involvement in the Caucasus was seen by Moscow as nothing but a clear manifestation of the British imperialists' anti-Sovict campaign with the ultimate aim of the destruction of the socialist régime in Russia. The British, on the other hand, still considered the Caucasian events part of the old 'Great Game' along the ninetecnth-century imperialistic lines. ${ }^{110}$ It was an imperial concept of the power struggle for the Asian provinces between Britain and the 'Russian Bear'.

This mutual fear and suspicion resulted both sides instructing their representatives not to enter into any kind of co-ordination to protect Baku from the Turkish invasion - thus leaving the men on the spot with a lack of direction. In this atmosphere of confusion and hesitancy, each side sought to

${ }^{109}$ Intervention and the War, p. 330.

110 In January 1831 , a British officer in disguise, 24 year old Lieutenant Arthur Conolly, was "sent into field to reconnoitre the military and political no-man's-land between the Caucasus and the Khyber, through which a Russian army might march". He was the "archetypal Great Game player, and it was he, fittingly enough, who first coined this memorable phrase in a letter to a friend". P. Hopkirk, The Great Game, Oxford, 1990 , p. 123. 
counter-balance the Turkish threat in its own pragmatic way. While the local Bolsheviks were trying to ally one national power (Christian Armenians) against the other (Muslim Azcrbaijanis), the British hoped that an antiTurkish, anti-German bloc (which included the Russians loyal to the Allied cause and the Christian nations of the region) could be formed.

The actions of the local Bolsheviks and those of the British in the Caucasus did not follow well-planned decisions but consisted rather of day-today tactical moves. These were pragmatic operations aimed to take advantage of the opportunities presented by the local circumstances. The local conditions themselves were changing fast, urging quick responses sometimes conflicting to each other. As a result, out of this confusion, the actions of the British and the Bolsheviks could not be coordinated and the control of the region casily fell to the Turks. 